Portland State University

PDXScholar

5-1977

\title{
Attitudes and Perceptions of Medical Social Workers Held by Primary Care Physicians in Private Practice, Defined as Family Practitioners, Internists, and Pediatricians
}

Rosemarie Rosenfeld

Portland State University

Follow this and additional works at: https://pdxscholar.library.pdx.edu/open_access_etds

Part of the Social Work Commons

Let us know how access to this document benefits you.

\section{Recommended Citation}

Rosenfeld, Rosemarie, "Attitudes and Perceptions of Medical Social Workers Held by Primary Care Physicians in Private Practice, Defined as Family Practitioners, Internists, and Pediatricians" (1977). Dissertations and Theses. Paper 1909.

https://doi.org/10.15760/etd.1909

This Thesis is brought to you for free and open access. It has been accepted for inclusion in Dissertations and Theses by an authorized administrator of PDXScholar. Please contact us if we can make this document more accessible: pdxscholar@pdx.edu. 
ATTITUDES AIND PERCEPTIONS OF MEDICAL SOCIAL WORKERS HELD BY PRIMARY CARE PHYSICIAIIS IN PRIVATE PRACTICE, DEFIINED AS FAMILY PRACTITIONERS, INTTERNISTS, AND PEDIATRICIAIIS

by

ROSEMARIE ROSEINFELD

A practicum submitted in partial fulfillment of the requirements for the degree of

MASTER of SOCIAL WORK

Portland State University

1977 
TO THE OFFICE OF GRADUATE STUUIES AiND RESEARCH:

The advisor approves the practicum of Rosemarie Rosenfeld presented May , 1977.

Quentin D. Clarkson, Ph.D., Advisor 
TABLE OF CONTENTS

PAGE

LIST OF TABLES ................... . . . . . vi

CHAPTER

I INTRODUCTION ................ 1

I I REVIEW OF THE LITERATURE . . . . . . . . . . . . 4

The History of Medical Social Work. . . . . 4

The Relationship between Physician

and Social Worker.... . . . . . . 6

In Education . . . . . . . . . 11

II METHODOLOGY. . . . . . . . . . . 14

Overview of the Research Design . . . . 14

The Population ......... 15

The Pre-Test ......... 16

Data Gathering Procedure ...... 16

Organization and Analys is of Data... . 17

IV RESULTS OF THE STUDY . . . . . . . . . . 18

V CONCLUSIONS AND RECOMMENDATIONS . . . . . . 23

Limitations of the Study ....... 23

Conclusions ......... 29

Recommendations . . . . . . . 32

BIBLIOGRAPHY . . . . . . . . . . . . 34

APPEHDIX . . . . . . . . . . . . . 37 


\section{LIST OF TABLES}

TABLE

PAGE

I Familiarity with the Role and Function of

Medical Social Workers.......... 19

II Do You Ever Refer Patients to a lledical

Social Worker? . . . . . . . . . 19

III Ratings of Different Practitioners as to

Ability to do Psycho-social Counseling . . . . . 21

IV Appropriate Practice Settings for Medical

Social Workers ............ 22

$\checkmark$ Number of Referrals of Patients to Social

Workers per Month ........... 24 24

VI Social Service Agencies which Physicians

Refer to Most Frequently ......... 25

VII Could You Use a Medical Social Worker in

Your Office?.................. 26 
CHAPTER I

\section{IINTRODUCTION}

In 1900, two out of three working in the health care field were physicians. How one out of twelve is. (Fuchs, 1974, p. 56) In view of today's complex technology, along with the changing nature of health problems, and the demand for access by a growing population, the diagnosis, treatment, and prevention of $i 11$ ness depends on the skills of numerous other health professionals. Medical social services originated early in this century and added a new dimension to medical care. Butryn (1967, p. 5) cites the central characteristic of medical social work is its direct concern with the social and emotional problems connected with illness and its medical treatment, and with any consequent adjustments in the lives of patients and their families.

All medical services are concerned with the promotion of health and the treatment of $i l 1$ ness. The relevance of social and emotional factors as connected with illness are viewed differently by physicians and social workers, as their approach to the patient varies. As an expert in the realm of diagnosis and treatment, the physician approaches illness with a definite and authoritative attitude. The social worker emphasizes helping the person to reach his own decision by enabling him to become aware of and take into account, as many as possible of the relevant factors, and then assisting him to carry out his decision. The problem of collaboration between social work and medicine is therefore not one of incompatibility between their respective aims, but one of a 
difference in approach, emphasis, and priorities. As health services increasingly call for an interdisciplinary approach today, the teamwork concept which social work literature and philosophy espouses, conflicts with the vertical chain of command historically favored by the physician.

Primary Practice is Patient Oriented

How the primary care physician, defined by Fuchs (1974) as "care given by practitioners who agree to serve as the first point of contact for the patient who needs or thinks he needs health services," (p. 6) views, reacts to, and accepts the medical social worker is investigated in this study. A review of the literature in this area revealed a paucity as only two investigations into the attitudes of physicians in private practice toward social workers or social services were found. In these studies a majority of the general practitioners who responded were unclear about the role and functions of social workers and had little contact with social worker agencies. (Langford, 1974; Harwin, 1970)

This is an exploratory study intended to determine whether certain physicians in primary practice utilize the services of social workers and social agencies. An attempt is made to find out how much primary care physicians know about the role and functions of medical social workers, and whether and for what services they refer patients to medical social workers. The information obtained may be useful in promoting better working relationships between the two professions.

The study revealed that while physicians are concerned with the psycho-social and economic problems of their patients, particularly 
the elderly, they are not very aware of all the roles and functions of medical social workers. Education is needed in this area. The literature contains a number of references to social workers being affiliated in offices with physicians. Only one such situation exists among the Portland sample. Many physicians still see the social worker as working only with the lower economic strata, and commented that in their practices they do not see patients who need social work services.

The response rate to the questionnaire was $98.2 \%$, which is indicative of interest, if not of strong opinion. 
CHAPTER II

\section{REVIEW OF THE LITERATURE}

This review traces medical social work from its origins in the hospital setting. As the total health and medical care system evolved during this century the social worker moved into new areas. Social workers have no monopoly on their services and they overlap and compete with other practitioners. Their role and function has not been clearly defined, nor has it been well understood. The literature, therefore, discusses the problems of the successes of the working relationship between physicians and medical social workers. Pediatricians were the first to work closely with social workers and other specialists have slowly followed. Advances toward a better understanding in the field of medical and social work education is included, along with a review of previous studies.

\section{The History of Medical Social Work}

Sensing a need for deeper understanding of the patient's social situation as it affected medical problems, Dr. Richard Cabot initiated medical social services at the Massachusetts General Hospital in 1905. The intent of this new concept in medical care was to treat the patient as an individual and to help him to make more effective use of what the physician and the hospital had to offer.

From serving hospitalized and outpatient clinic patients, medical social services spread to other areas including Tuberculosis, rehabilitation, and mental health. Since 1920, public health programs have included 
social workers at all levels. The Social Security Act of 1935 and later amendments have added impetus to medical social services, particularly Title XVIII, which in 1966 added funds for medical care coverage for the over 65 population and the medically indigent.

Usually medical social services are under the aegis of hospital social service departments. In $1972,3,179$ out of 7,800 hospitals responding to a survey by the American Hospital Association reported having such departments. Smaller hospitals are less likely than larger ones to offer these services. (Brocht, 1974)

The literature reveals social workers using various methods in a variety of other settings, role definitions and functions. In the health care field social workers are clinicians, administrators, teachers, and researchers. Casework is the method most used and is largely dependent on referral by physicians. According to the Encyclopedia of Social Work, this tends to inhibit the widest use of social workers since referrals are "often limited by the physician's perception of what it is the social worker can offer, his previous training, and/or his resistance to sharing a patient with other colleagues." (Phillips, 1971, p. 270) Cultural variables also affect the physician's attitude toward the physical illness of the patient, or their families, determining the type and timing of requests which reach the social worker. (Gordon, 1969, p. 36) He goes on to say that the physician therefore defines social need and his decision determines the timing of intervention.

Through agencies and community organizations such as the Visiting Nurses Association, welfare, community health clinics, hospitals and 
schools, social workers provide counseling, guidance, and psychotherapy to individuals and families. The private practice of casework first began in the $1940^{\prime} s$. In 1957 private practitioners were accepted into the field of social work and were defined as being outside of an estab1 ished institution, public or private, and solely responsible for their own practices. Private practitioners are moving from referrals from physicians to their own. (Encyclopedia of Social Work, 1971, p. 950) Health is the third largest industry in the United States, employing five percent of the labor force. One-third of the members of the National Association of Social Workers are in the health field providing services to people in a11 economic groups. (Brocht, 1974)

The Relationship Between Physician and Social Worker

The effectiveness of the medical social worker depends in large part on the ability to communicate with other members of an interdisciplinary team, who have a different frame of reference. The term "Health team" is a figure of speech to Fuchs, because the "captaincy" by the physician is beyond doubt. The doctor controls the progress of health care, others--pharmacists, nurses, technicians, and the like--control delivery and all report back to the physician and take his instruction. (Fuchs, 1974, p. 56) Or in the words of Dr. Merritt B. Low, who in his presidential address at the annual meeting of the American Academy of Pediatrics stated, "it is evident that in some situations a 'so-called team approach is in the offing.' Where such an approach using allied health workers is necessary or desirable, and local option should 
certainly prevail, the pediatrician should be in a supervisory role, to go with his or her responsibility." (1976) Ratoff (1974) contends that many doctors are ignorant about the training, roles and responsibilities of social workers because they seldom have had first hand experience of receiving help from social workers, though social workers are patients of doctors. Studies at Beth Israel Hospital in Boston conclude that physicians have an incomplete perception and understanding of the function of social work services and underestimate the social worker's role. Doctors do not accept the social worker's perception that his skills lie in social casework or in working with psycho-social problems of families. (Phillips, 1971) According to Hollowitz (1972) social workers complain that physicians consider them handmaidens, financial agents, or body movers rather than professional colleagues. (1972, p. 90)

The literature discussing cooperation between physicians and social workers is sparse. It is authored either by social workers or physicians, or in collaboration about a particular situation. Pediatrics was the first specialty in medicine to recognize and work with social workers. Dr. Eugene Schuster wrote in 1951 ,

The social worker can round out the physician's conception of his patient in terms of his day-to-day living; his relationships to his family, to other children, to his teachers in school; in fact, to all people or groups or institutions which impinge upon his life. Since these relationships are just as vital a factor in the child's well-being as vitamins or operations, the pediatrician should seek out and learn to utilize information from the medical social worker and discover the ways in which she can integrate her efforts with his. 
While Schuster felt that a time was coming when the physician in private practice would be utilizing medical social workers as a matter of course, the following were the only articles to be found of examples of this occurring in the area of pediatrics. Beal1 and Green (1960) describe a children's diagnostic clinic in which the medical social worker is part of the medical team and consults with the physician in setting patient goals, provides parent education, and works with schools, welfare departments, children's institutions, courts, and child guidance clinics.

According to Wishingrad (1963), casework should be highly selective as most parents need only advice and reassurance, and do not need or resist psychiatric referral. The social worker in a pediatric office has the interview techniques, the time, the knowledge of community resources, and the familiarity with agency personnel to evaluate the patient for the physician who has the final responsibility.

Writing in the American Journal of Diseases of Children, Dr. Edward Townsend stated that pediatrics is becoming more complicated as problems in development, behavior and education are added to those faced in the treatment and prevention of disease. The physician needs to be more diverse. The social worker on the staff of his practice is called on only when a family needs more time than the physician can allow.

In an article entitled "Social Work Assistance in a Private Pediatric Practice," Korpela (1973) describes how she can identify vulnerable children and families and thus anticipate problems. She 
provides direct services to individuals, families and groups of parents, either by request or medical referral.

Turning now to other areas of medicine, a social worker and surgeon (Strozier and Ballinger, 1975) collaborated to write that while a psychiatrist works with drugs and therapy to help the mentally ill recover, a medical social worker deals with normal people who are faced with a crisis, such as hospitalization or surgery and require short term counseling. Gang (1975) states that some problems cannot be solved by physicians with medical means alone. The doctor can try to deal with them, ignore them, or refer to a psychiatrist. However, psychiatrists focus on major psychiatric conditions. Social workers can, in his opinion, increase the effectiveness of a physician by adding another dimension or point of view in the areas of marital and family counseling, isolation and bereavement, physical disability, care of the elderly, housing and financial problems.

There are only half as many physicians in the United States as are needed in order to provide the required primary medical care for the population, according to Schonfeld, writing in the llew England Journal of Medicine. He feels that part of the solution to the problem would be the transfer of activities to other providers. (1972, p. 574) Alexander (1976) concurs and suggests that some of the expensive medical care system including rehabilitating stroke victims, genetic counseling, and renal therapy could effectively be transferred into the social care system. 
Blatterbauer, Kupst, and Schulinan (1976) discuss how the social worker can enhance the relationship between physician and patient. "Recognizing that physicians need to deal with patient's emotional and cognitive needs as well as the physical, the social workers intervention helps families assimilate medical information and resolve emotional issues when the physician does not have the time or the opportunity to meet all the patient's needs." ( $p .47$ )

After a successful two year experience of having a social worker affiliated with him in his office a consulting gastroenterologist reports, "Social intervention is one of the essential aims of successful primary health care delivery at the community level, and social casework is an important part of such intervention." (Baum, 1973, p. 189) The social worker provided skilled assistance in resolving some material, emotional, or personality problem, saving the physician time so that he could attend to problems he might otherwise have ignored. One out of 35 patients in the practice saw her for some of these problems: coping with severe or prolonged illness, terminal illness, bereavement, inadequate home help, psychiatric support, marriage breakdown, or vocational problems. (p. 90)

A psychiatrist (Forman, 1976) refers patients to a medical social worker for non-medical or social problems, and feels that many social workers are capable of doing independent therapeutic work in private practice. Goldberg, a medical social worker in a family practice setting, states that more than half of those who go to family physicians have emotionally based complaints. (1973) In the family medical center 
at the University of Washington, the medical social workers referred patients to 106 different community resources. (Lincoln and Twersky, 1974)

More people consult the medical doctor about marriage problems than for any other professional help, according to a social worker employed in a clinic with four obstetricians. (Klemer, 1966) Here the social worker is additional to the services of the doctor and is non-competitive since he is involved in an entirely different profession. The patients are not referred away, rather the patient-doctor relationship is enhanced by the availability of counseling in the same office.

\section{In Education}

Some of the problems of cooperation, collaboration, and acceptance of each other's skills may be due to the fact that until recently the role of the social worker was not explained to the medical student. (Bea11, 1966) In the book, Boys in White, a study of student culture in medical school, Becker states that "Physicians work with registered nurses, practical nurses, aides and maids, technicians, therapists, accountants, personnel men and administrators." (1961, p. 8)

While the medical student may be impatient with so much to learn and resentful of non-medical faculty and subject matter, other aspects of a patient's life situation are involved in comprehensive medical care. Edelson, in reviewing the role of the social worker in medical education, stresses that knowledge of helping agencies and how to use community resources, and understanding the impact of illness on the 
individual and his family, are essential in the teaching of comprehensive patient care. Social workers have been on the faculties of some medical schools since 1952. (1965) As of July 1975, 595 social workers were teaching in 116 accredited medical schools with primary faculty appointments. (Grinnell, 1976, p. 319) Fifty-one percent were in psychiatry, fourteen percent in pediatrics, and the rest in family and community medicine. However, twenty-two percent of the medical schools surveyed by the Association of American Medical Colleges do not employ social workers on their faculty.

Another approach toward physician and social work education has been in practice at Wayne State University in Ohio where second year graduate social work students are placed with family physicians in private practice for field experience. Goldberg maintains that this is educational both for the student and the physician, who begins to accept the contribution the social worker can make to his practice as a member of the health team. (1973)

A literature search revealed the following two studies in this area. The Tasmanian study (langford, 1974), which was a survey of attitudes of general practitioners to social workers, was based on a 1970 study (Harwin et al.) of the attitudes of 123 general practitioners in London toward social services.

Harwin found that few general practitioners had any regular contact with social service agencies, be they mental health, Alcoholics Anonymous, schools, or welfare. Family doctors make little use of the existing agencies, and, indeed, are often unclear as to the functions 
of these services. Using social services to help with such problems as employment, behavioral problems with children, unmarried mothers, and chronic illness were infrequently mentioned, while alcoholism and drug dependence were not mentioned at all. (p. 561)

The author continues that as far as a "medicosocial team" few are aware of the need, most have given the subject little thought and are indifferent, and a substantial minority are opposed. In their relations with social workers few had criticisms, possibly red tape or lack of communication, but it was more a question of lack of awareness than hostility. (p. 561)

The Langford study in Hobart revealed that fifty-seven percent of the general practitioners questioned had occasional contact with social service agencies, twenty percent had non or infrequent contact, and six percent regular contact. Thirty-four percent of the respondents felt that they understood the role and function of social workers. Seventy-five percent indicated that social workers should not be in private practice, and "Many of the doctors viewed with some uncertainty the competence of social workers in handling a wide range of psycho-social problems." (Langford, 1974, p. 433)

This literature review has discussed the history of medical social work, described attitudes of physicians in private practice and social workers toward each other, mentioned some of the roles and functions of medical social workers in various settings, including medical and social work education. These points provide a basis for the study which follows. 


\section{CHAPTER II I}

\section{METHODOLOGY}

This exploratory study attempts to determine the attitudes and perceptions of primary care physicians, internists, general and family practitioners and pediatricians in private practice, toward medical social workers and whether and how they interact and use their services. Social work literature refers often to the health care team and the growing importance of the role of medical social workers in providing health related services. However, as the literature search revealed only two other studies on this particular subject and few on the interaction of doctors and social workers, it could be assumed that in general physicians do not interact much with social workers, do not refer patients to them, give them little thought, or are simply never asked.

It appears valid to ascertain therefore, whether physicians in specialties most likely to deal with medical social workers, have knowledge of and do work with social workers. Following is an overview of the research design, a description of the population, discussion of the data gathering procedure, and the method of organization and analysis of the data.

\section{Overview of the Research Design}

The questionnaire began by asking how familiar physicians felt themselves to be with the role and function of medical social workers. The physicians were then asked how they felt about the psycho-social 
counseling skills of social workers compared to other practitioners. Whether physicians used the services of medical social workers was determined by asking whether patients were referred to social workers or social service agencies, how often, and for what reasons.

It was asked what practice settings were felt to be appropriate for medical social workers, and whether the respondent could use a person with the skills of a medical social worker in his office. Finally, the physicians were asked whether they experience any problems in dealing with social workers, and if so, what the major ones are.

Having been advised that physicians receive myriad questionnaires to which they do not necessarily respond, this instrument was kept simple, brief, and to the point.

\section{The Population}

Internists, general practitioners, family practitioners, and pediatricians practicing in Portland were the population for the study. These physicians, where they practice and their specialty are listed in the Directory of Registered Licensees published by the Board of Medical Examiners of the State of Oregon. Since only physicians in private practice were to be included in the sample frame, doctors affiliated with the Kaiser Permanente Medical Care Program, the Cascade Health Care Organization, and the University of Oregon Medical School were el iminated. Doctors in private practice with offices listed in the telephone directory comprised the sample frame which was then stratified as to specialty. The frame included 146 internists, 
102 family and general practitioners, and 35 pediatricians. A twenty percent random sample resulted in 30 internists, 20 general and family practitioners, and 7 pediatricians being in the study. Family and general practitioners will from now on be combined into a general practitioner category.

The Pre-test

The questionnaire was hand delivered on February 1, 1977 to three internists and one pediatrician, who were not in the sample, for pretesting and comments. A handwritten letter of explanation was enclosed along with a stamped return envelope. Three responses were returned within four days and one was never received.

The pilot resulted in the elimination of a question which asked, "What percentage of your patients would you estimate have emotional problems?" Every respondent questioned this, and one said it was an established fact, the answer being $70 \%$. A question asking for problems experienced in dealing with social workers was added, as the result of a suggestion. Another line for answering two "open" questions was added.

\section{Data Gathering Procedure}

The questionaire, cover letter with a red, heart-shaped lollypop taped to it, and a stamped, addressed envelope were enclosed in a $9 \times 12$ manila envelope and hand delivered on Monday, February 7 , to doctors located on the west side of Portland, and on February 8 to those on 
the east side. Three responses were received on February 8 , with 13 , 11 , and 10 returned on the following three days. The forty responses tabulated by the end of the week were 70 percent of those sent out. A follow-up was mailed on February 15. Written in red pencil on the same cover letter was, "Have you eaten the lollypop and not returned the questionnaire?" The outline of the lollypop was drawn in red at the bottom of the page. Another questionnaire and envelope were enclosed.

This turned out to be an effective reminder, for between February 18 and March 16, all but one of the total of 57 questionnaires were returned for a 98.2 percent response rate.

\section{Organization and Analysis of Data}

When 56 questionnaires had been received, answers to the fifteen questions which were appropriate were coded, key punched, and programmed for frequency and percentages, separated as they had been stratified according to the three specialties. The four questions which had open-ended responses were catagorized manually, along with other comments which were also recorded, as some respondents were rather verbose. The findings follow. 


\section{CHAPTER IV}

\section{RESULTS OF THE STUDY}

The purpose of the study was to investigate the attitudes of internists, general practitioners, and pediatricians in private practice toward medical social workers. The sample included thirty internists, twenty general practitioners, and seven pediatricians. Except for one internist and one general practitioner, the physicians were men. The range of years in practice was from six months to forty years. The average years in practice was seventeen for the internists, twenty-two among the general practitioners, and ten among pediatricians. Overall, thirty percent of the physicians had been in practice ten years or less, twenty-five percent between eleven and twenty years, eighteen percent from twenty-one to thirty years, and twelve percent have been in practice over 30 years.

The questionnaire attempted to explore whether these physicians are familiar with the role and function of medical social workers, how they feel about them and get along with them, and whether they use their services. The questionnaire asked eight specific questions. Table I indicates the response to the first question, How familiar are you with the role and function of medical social workers?

Table I shows that the majority of the physicians, or fifty-seven percent felt themselves somewhat familiar with the role and function of medical social workers, while forty-one percent felt very familiar. One pediatrician admitted to being unfamiliar. 


\section{TABLE I}

FAMILIARITY WITH THE ROLE AND FUNCTION

OF MEUICAL SOCIAL WORKERS

\begin{tabular}{|c|c|c|c|c|c|c|c|c|}
\hline & \multicolumn{2}{|c|}{$\begin{array}{c}\text { Internists } \\
n=30\end{array}$} & \multicolumn{2}{|c|}{$\begin{array}{c}\text { General } \\
\text { Practitioners } \\
n=20\end{array}$} & \multicolumn{2}{|c|}{$\begin{array}{l}\text { Pediatricians } \\
n=6\end{array}$} & \multicolumn{2}{|c|}{$\begin{array}{r}\text { Total } \\
n=56\end{array}$} \\
\hline & $n$ & $\%$ & $n$ & $\%$ & $n$ & of & $n$ & $\%$ \\
\hline Very Familiar & 13 & 43.3 & 6 & 30 & 4 & 67.0 & 23 & 41.0 \\
\hline $\begin{array}{l}\text { Somewhat } \\
\text { Familiar }\end{array}$ & 17 & 56.6 & 14 & 70 & 1 & 16.0 & 32 & 57.0 \\
\hline Unfamiliar & - & - & - & - & 1 & 16.0 & 1 & 1.7 \\
\hline
\end{tabular}

In order to attempt to determine whether these physicians interact with social workers and make use of their services, they were asked whether they ever refer patients to a social worker for counseling or other help, and if so, for help with what kinds of problems.

TABLE II

DO YOU EVER REFER PATIEITTS TO A MEDICAL SOCIAL WORKER

\begin{tabular}{|c|c|c|c|c|c|c|c|c|}
\hline & \multicolumn{2}{|c|}{$\begin{array}{l}\text { Internists } \\
n=30\end{array}$} & \multicolumn{2}{|c|}{$\begin{array}{c}\text { General } \\
\text { Practitioners } \\
n=20\end{array}$} & \multicolumn{2}{|c|}{$\begin{array}{l}\text { Pediatricians } \\
n=6\end{array}$} & \multicolumn{2}{|c|}{$\begin{array}{r}\text { Total } \\
n=56\end{array}$} \\
\hline & $\mathrm{n}$ & $\%$ & $n$ & $\begin{array}{l}\% 1 \\
\end{array}$ & $n$ & $\%$ & $n$ & $\%$ \\
\hline Yes & 25 & 83.0 & 19 & 95.0 & 3 & 50.0 & 47 & 83.9 \\
\hline Ho & 4 & 13.0 & 1 & 5.0 & 3 & 50.0 & 8 & 14.2 \\
\hline No Answer & 1 & 3.3 & - & - & - & - & 1 & 1.7 \\
\hline
\end{tabular}


As seen in Table II all but one general practitioner responded that he referred patients to medical social workers, while eighty-three percent of the internists and half the pediatricians do. When asked for help with what kinds of problems, ten internists, four general practitioners and four pediatricians did not specify. Those who did respond mentioned these problems most frequently: family problems, home assistance, nursing home placements, hospital discharge planning, and economic, including welfare, pension, and occupational. Also noted were problems dealing with marriage and parent-child relationships, care of the elderly and rehabilitation. One pediatrician mentioned child abuse.

The respondents were asked, based on their own experience, to rate various practitioners as to their ability to do psycho-social counseling. While psychiatrists and psychologists were felt to be the most able, this question elicited the widest range of answers of any. According to Table III internists felt that psychologists were less able to counsel than psychiatrists, though pediatricians did not have the same confidence in psychiatrists that the others listed. Medical social workers and clergymen were rated about the same, mostly somewhat able. Only one general practitioner felt that medical social workers were not able to counsel, and medical social workers were rated the highest of any practitioner, when the very able and somewhat able categories are combined. The no response and no answer response was rather high, ranging from twelve to sixteen percent of the answers to these four questions. 
TABLE I I I

RATINGS OF DIFFERENT PRACTITIONERS AS TO ABILITY

TO DO PSYCHO-SOCIAL COUNSELING

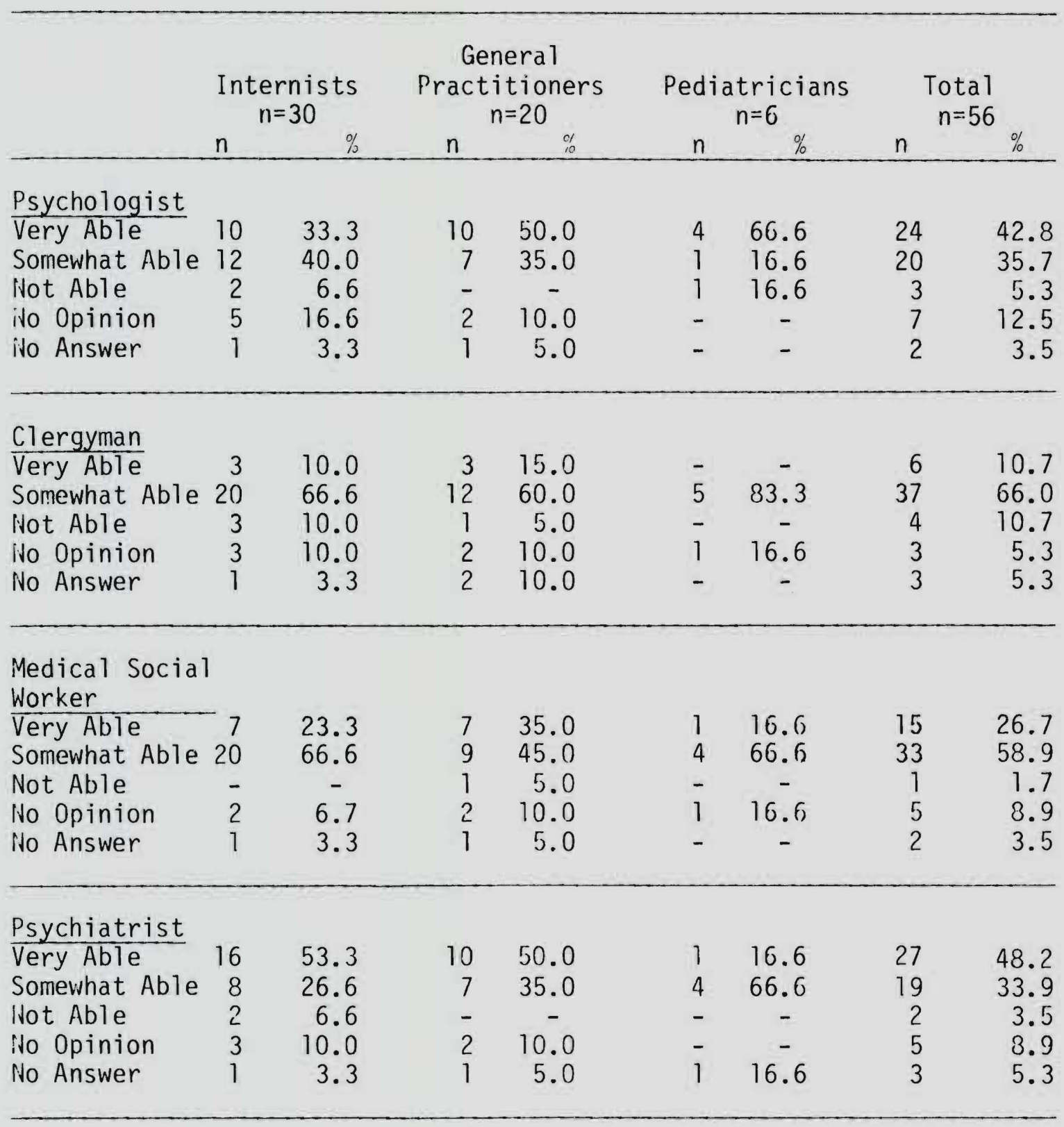

There was general agreement that the most appropriate practice settings for medical social workers are the community hospitals and the social service agencies, as the following table indicates. 
TABLE IV

APPROPRIATE PRACTICE SETTINGS FOR MEDICAL SOCIAL WORKERS

\begin{tabular}{ccccc}
$\begin{array}{c}\text { Internists } \\
n=30\end{array}$ & $\begin{array}{c}\text { General } \\
\text { Practitioners } \\
n=20\end{array}$ & $\begin{array}{c}\text { Pediatricians } \\
n=6\end{array}$ & $\begin{array}{c}\text { Total } \\
n=56\end{array}$ \\
\hline
\end{tabular}

Community Hospitals

Very Appropriate 27

Somewhat Approp.

Ilot Appropriate -

No Opinion

$\begin{array}{ll}90.0 & 12 \\ 10.0 & \\ - & \end{array}$

60.0
35.0
5.0

$\begin{array}{cc}5 & 83.3 \\ 1 & 16.6 \\ - & - \\ - & -\end{array}$

44

78.5

$11 \quad 19.6$

$-$

Private Social Work Practice

$\begin{array}{lrrrrrrrr}\text { Very Appropriate } & 6 & 20.0 & 7 & 35.0 & 2 & 33.3 & 15 & 26.7 \\ \text { Somewhat Approp. } & 15 & 50.0 & 7 & 35.0 & 2 & 33.3 & 24 & 42.8 \\ \text { INot Appropriate } & 3 & 10.0 & 4 & 20.0 & 2 & 33.3 & 9 & 16.0 \\ \text { No Opinion } & 6 & 20.0 & 2 & 10.0 & - & - & 8 & 14.2\end{array}$

Affiliated in Offices with Physicians

$\begin{array}{lrrrrrrrr}\text { Very Appropriate } & 2 & 6.6 & 3 & 15.0 & - & - & 5 & 8.9 \\ \text { Somewhat Approp. } & 11 & 36.3 & 6 & 30.0 & 5 & 33.3 & 22 & 39.2 \\ \text { Not Appropriate } & 10 & 33.3 & 4 & 20.0 & 1 & 16.6 & 15 & 26.7 \\ \text { No Opinion } & 7 & 23.3 & 7 & 35.0 & - & - & 14 & 25.0\end{array}$

\section{Social Service Agency}

$\begin{array}{lrrrrrrrr}\text { Very Appropriate } & 23 & 76.6 & 14 & 70.0 & 5 & 83.3 & 42 & 75.0 \\ \text { Somewhat Approp. } & 4 & 13.3 & 4 & 20.0 & 1 & 16.6 & 9 & 16.0 \\ \text { ilot Appropriate } & - & - & - & - & - & - & - & - \\ \text { No Opinion } & 2 & 6.6 & 2 & 10.0 & - & - & 4 & 7.1 \\ \text { ilo Answer } & 1 & 3.3 & - & - & - & - & 1 & 1.7\end{array}$

As indicated in Table IV, no respondent felt that the hospital or the social service agency was not an appropriate setting for a medical social worker. However, four physicians had no opinion on whether social 
workers were appropriate in a social service agency, and one did not answer that question. Opinion was more dispersed as to whether medical social workers should be in private practice or affiliated in offices with physicians. Only six percent of the internists felt that social workers are appropriately affiliated in offices with physicians, while one-third felt it not appropriate. Eighty-three percent of the pediatricians felt social workers were "somewhat" appropriate in this setting. Twenty-five percent of the total sample had no opinion on this subject. Among internists and general practitioners, forty-two and forty-five percent respectively felt that social workers were very or somewhat appropriate in a setting of being affiliated with physicians. However, fifty-eight percent of the entire sample of physicians who have been in practice ten years or less, compared to forty-three percent of those in practice more than ten years, indicated that response. (See Appendix.)

More physicians would rather see medical social workers in private practice, than affiliated in offices with them. Seventy percent of internists and general practitioners felt that private practice is at least "somewhat" appropriate as a setiing for medical social workers. The number of years in practice resulted in very little difference of opinion. The response of the pediatricians was mixed and inconclusive. One physician replied that social workers were particularly appropriate in private practice when specializing in marital counseling. Another mentioned that social workers in private practice, "tend to get too expensive for those who need them." 
Most physicians refer patients to medical social workers less than three times a month. The mean number of referrals is 2.2 for internists, 1.9 for general practitioners, and 2.1 for pediatricians. Internists do the most referring, as is shown in Table $V$.

TABLE $V$

NUMBER OF REFERRALS OF PATIENTS TO SOCIAL WORKERS PER MONTH

\begin{tabular}{|c|c|c|c|c|c|c|c|c|}
\hline \multirow{2}{*}{$\begin{array}{l}\text { Number of } \\
\text { Referrals } \\
\end{array}$} & \multicolumn{2}{|c|}{$\begin{array}{c}\text { Internists } \\
n=30\end{array}$} & \multicolumn{2}{|c|}{$\begin{array}{c}\text { General } \\
\text { Practitioners } \\
n=20\end{array}$} & \multicolumn{2}{|c|}{$\begin{array}{c}\text { Pediatricians } \\
n=6\end{array}$} & \multicolumn{2}{|c|}{ Total } \\
\hline & $n$ & $\%$ & $n$ & $\%$ & $\mathrm{n}$ & $\%$ & $\mathrm{n}$ & $\%$ \\
\hline More Than 10 & 5 & 16.6 & 1 & 5.0 & - & - & 6 & 10.7 \\
\hline 3 to 10 & 6 & 20.0 & 5 & 25.0 & 2 & 33.3 & 13 & 23.2 \\
\hline Less than 3 & 12 & 40.0 & 8 & 40.0 & 3 & 50.0 & 23 & 41.0 \\
\hline Rarely & 4 & 13.0 & 4 & 20.0 & 1 & 16.0 & 9 & 16.0 \\
\hline No Answer & 3 & 10.0 & 2 & 10.0 & - & - & 5 & 8.9 \\
\hline
\end{tabular}

The responses ranged from never to thirty times per month. A 1 ist of the agencies which doctors refer patients to, and the number of times each agency was mentioned is presented in Table VI. Forty respondents referred to ten agencies.

There was general consensus among the respondents, as ninety percent of the internists, eighty percent of the general practitioners, and all the pediatricians, stated that they could not use a person 
TABLE VI

SOCIAL SERVICE AGENCIES WHICH PHYSICIANS REFER TO

MOST FREQUEINTLY

\begin{tabular}{|c|c|c|c|c|}
\hline Agency & Internists & $\begin{array}{c}\text { General } \\
\text { Practitioners } \\
\end{array}$ & Pediatricians & Total \\
\hline $\begin{array}{l}\text { Hospital Social Work } \\
\text { Department }\end{array}$ & 15 & 6 & 1 & 22 \\
\hline Visiting Nurses Assoc. & 9 & 6 & - & 15 \\
\hline Welfare & 2 & 2 & 1 & 5 \\
\hline Family Counsel ing & 2 & 1 & - & 3 \\
\hline $\begin{array}{l}\text { Multnomah County Health } \\
\text { Nurse }\end{array}$ & 2 & 2 & - & 4 \\
\hline Catholic Charities & - & 1 & - & 1 \\
\hline $\begin{array}{l}\text { Metropolitan Family } \\
\text { Service }\end{array}$ & 1 & - & - & 1 \\
\hline $\begin{array}{l}\text { Jewish Family and Child } \\
\text { Service }\end{array}$ & - & 1 & 1 & 2 \\
\hline Child Care Agencies & - & - & 2 & 2 \\
\hline Mental Health & - & 2 & - & 2 \\
\hline No Answer & 9 & 4 & 3 & 16 \\
\hline
\end{tabular}

with the skills of a medical social worker affiliated with them in their offices. Table VII indicates that all respondents answered this question. Sixteen respondents gave no reason as to why they felt this way, but others mentioned the following reasons why they could not use a person with the skills of a medical social worker affiliated with them in their offices. 
TABLE VII

COULD YOU USE A MEDICAL SOCIAL WORKER IN YOUR OFFICE?

\begin{tabular}{lrrrrrrrrr} 
& \multicolumn{1}{c}{$\begin{array}{c}\text { General } \\
\text { Internists } \\
n=30\end{array}$} & $n$ & $\begin{array}{c}\text { Practitioners } \\
n=20\end{array}$ & \multicolumn{1}{c}{$\begin{array}{c}\text { Pediatricians } \\
n=6\end{array}$} & $\begin{array}{c}\text { Total } \\
n=56\end{array}$ \\
\hline Yes & 3 & 10.0 & 4 & 20.0 & - & - & 7 & 12.5 \\
Ho & 27 & 90.0 & 16 & 80.0 & 6 & 100.0 & 49 & 87.5 \\
\hline
\end{tabular}

Nine physicians said they did not have enough volume to keep a social worker busy. Eight stated there was no need. Six said it was too expensive, and another six said their office was too small. One said he did the work a social worker would do and one said his nurse did it. One doctor felt that other agencies did those things sufficiently, one said it was not appropriate, and one felt that his patients would not accept it.

One respondent answered yes and 110 , that social workers have a place in private practice, but he has no room for one in his general practice. Two physicians responded that social workers are "not frequently needed in socio-economic group seen in my private practice." Or, "In clinic or hospital work, which deals with those of the lower socio-economic categories, the medical social worker has the greatest opportunity for application of her skills." One pediatrician did write, "Doesn't appear to be a need. If I knew all the services they could provide I might change this opinion." 
Of the seven physicians who responded that they could use a medical social worker in their practice, one general practitioner who has been in practice for twenty-five years, has had a social worker in his clinic for the past seven years. Two other general practitioners, in practice for twenty-four and three years respectively, stated that they could use a social worker part-time. Two pediatricians, each in practice one year saw the possibility of having an affiliation with a medical social worker, possibly one-half day per week. Three internists were interested in this arrangement, two have been in practice six years and one twenty-five years. They felt it would be feasible in a group practice, though one stated that the cost could not be carried until medicare or welfare paid for the social worker's services.

The final question dealt with possible problems the physicians have in dealing with medical social workers. Twenty-six physicians or forty-six percent of the respondents mentioned having no problems or did not answer this question. Several said they were generally pleased with their relationships with social workers. Some of the problems mentioned relate to red tape, delays and financial limits of the system. Problems in communication were mentioned most often. It was also mentioned that some social workers are not realistic, are not objective, lack imagination, are inflexible, oversimplify, call during busy office hours, do not understand the patient's needs, tend to act on their own and create hostility in patients and their families. Several physicians stated that they have more problems with welfare social workers than with medical social workers, but of ten these problem are not the fault of the worker. 
CHAPTER $V$

\section{COINCLUSIONS AND RECOMMENDATIONS}

\section{Limitations of the Study}

Whether the unusually high response rate of 98.2 percent was due to the simplicity of the questions, interest in the subject, or the result of enclosing a gift, the lollypop, the study had clear limitations. These will be discussed before drawing some conclusions and listing recommendations.

For fear of eliciting poor response from a population difficult to survey, the instrument was brief and easy to answer. It may have been too simple. The main question of determining the attitudes of physicians toward social workers has not really been answered. In asking physicians to rate the ability of various practitioners who do psycho-social counseling, the point was not made. It turned out to be an invalid question as the no opinion and no response rate was high, and nine percent of the physicians felt that since the answer depended on the individual, they could not respond to the question.

A twenty percent sample of pediatricians in Portland resulted in seven names. Six of these responded and since their answers were sketchy, their value is diminished. The one hundred percent response of the internists and general practitioners should be very representative of the opinion of those two groups of physicians. However, many were very brief or did not answer every question. It appears that 
the questionnaire was not one that was given much time or thought, and conscience may have dictated its return.

This study was unsolicited, and the response indicates that further investigation in this area may be of use. Do patients feel that physicians are dealing adequately with their psycho-social needs? How do medical social workers in hospitals and social service agencies relate to physicians? How can social workers overcome the resistance of the medical profession? From where do medical social workers in private practice obtain their clients?

\section{Conclusions}

This study showed that while all but one of the respondents felt that they were at least "somewhat" familiar, and forty-one percent felt that they were very familiar with the role and function of medical social workers, and though eighty-four percent refer patients to social workers, they do so less than three times per month. The pediatricians, who are the youngest group in the sample, have the poorest record as they are less familiar with and only half of them ever refer patients to social workers. If more is being taught in medical schools about patients' needs for total health care, pediatricians are not making use of social workers' services.

Reasons for referrals to social workers centered mostly on discharge planning, post-hospital care and nursing home placements, usually provided by a hospital social service depariment or the Visiting ilurse Association. The V.N.A. employs four medical social workers in Portland 
along with other practitioners who provide services under the prescription and direction of a licensed physician.

Utilization of the skills of medical social workers and community resources is obviously scanty. Only ten different social agencies were listed by respondents as ones they refer to. Lincoln and Twersky wrote that medical social workers affiliated with a family practice center referred patients to one hundred and six different agencies in Seattle during one half year (1974). A brief inconclusive summary of some of the job functions of medical social workers drawn from the literature includes in the area of pediatrics: group and individual counseling, helping families assimilate diagnosis, child guidance, family casework, dealing with school problems, child abuse and neglect, and financial assistance. With family practitioners areas of social work deal with: marital problems, family disturbances, depression, obesity, unwed pregnancy, drug and alcohol abuse, diabetes, anxiety, fatigue, arthritis, headaches, terminal illness, bereavement, inadequate home help, vocational problems, care of the elderly, housing, and finances. The findings of this study included very few of these problems.

It is axiomatic that every patient has an emotional as well as physical problem when he seeks professional help. (Smith, 1977) Are physicians within the time limitations of an average office visit able to treat both the physical problems and the psycho-social needs of their patients? Are they aware of community resources in order to make meaningful and necessary referrals? 
Physicians in the survey generally felt that medical social workers are as able to counsel as psychologists and psychiatrists, as seen in Table III. Overall, forty-four percent of the physicians feel psychologists very and somewhat able to counsel, forty-six felt so about psychiatrists, and forty-eight percent rate social workers in this manner. Yet most of their referrals to social workers are for other reasons.

That the respondents feel that social workers are most appropriate in hospitals and in social service agencies is not surprising, since these are traditional settings for social workers. Affilitations of physicians with social workers is discussed in the literature review, and one such arrangement was found in Portland. Only eight percent of those surveyed felt this to be an appropriate setting for social workers, though twenty-six percent felt that social workers were appropriate in private practice, where there is less threat and no expense. When asked whether a medical social worker would be useful in their offices, every physician responded--mostly negatively. Many referred to lack of volume, space, and funds. Mentioned in the literature but not in answers of this study is the unwillingness to share a patient. In the literature various ways to handle the doctor-patientsocial worker relationship, the management of office space and hours, the financial arrangements are discussed. But initially the physician must feel that there is a need for a medical social worker to help care for patients, and very few in this study do.

These responses do not vary much from those elicited by the Harwin and Langford surveys mentioned earlier. Few physicians have clear 
ideas of the role and function of the medical social worker, the social service agency and the help they provide. It was particularly interesting that in none of the three surveys did physicians mention any drug or alcohol abuse problem, and all noted that social workers should help the elderly.

While half the respondents in this study mentioned no problems in dealing with social workers, problems were also few in the other studies. This can be due to little contact and lack of knowledge, rather than any particular hostility.

\section{Recommendations}

The problems of collaboration between physicians and social workers are difficult to reconcile as long as medicine sees social work as an ancillary service, rather than part of a medicosocial team. However, social workers must define the responsibilities they want to assume and justify their choices. Social workers need to agree on their functions and acquire hard information to measure outcome, though it is difficult to quantify their work. That social workers have not set standards of quality control and collected such data, has kept social work treatment from coverage by health insurance. (Lyng, 1976)

Along with increased efforts toward accountability, social workers and community agencies need to provide physicians with information as to their services. Innovation and assertiveness along with good public relations can also be a beginning toward overcoming the resistance and apathy of the medical profession. Schools of Social Work need to stress 
the development of better communication skills in training medical social workers.

This study indicated that in Portland physicians appear to use the services of social workers for their hospitalized patients more than for ambulatory patients. Many respondents to this study expressed a concern for their elderly patients. Some indicated a need for a counseling source available to or in conjunction with physicians to help the elderly or handicapped with legal problems, understanding medicare, housing needs, combating loneliness, etc. While physicians noted that they could not afford the cost of a social worker in their office, the trend toward group practice is growing. A half-time social worker may become profitable for as small a group as a three-person practice, according to Hookey in a paper discussing the economics of social work in group medical practice, either as an employee of the group, or charging a fee for services.

Trust, understanding, and cooperation take time to develop, yet the problems of mental and physical health, injury, addiction, retirement and family problems become more prevalent among all economic groups. As the demand for comprehensive medical care for the total population increases, so must the roles, functions and settings of the medical social worker. 


\section{A SELECTED BIBLIOGRAPHY}

Alexander, Chauncey. "Health Care Engimas." Health and Social Work, 1 (1976), 11-15.

Barkan, T.W. "Private Casework Practice in a Medical Clinic." Social Work, 18 (1973), 5-9.

Baum, Peter, M.D. "The Social Worker in a Private Medical Practice." Medical Journal of Australia, 2 (1973), 188-191.

Beal1, Patricia and Morris Green, M.D. "The Role of the Social Worker in a Children's Diagnostic Clinic." Social Work, 10 (1960), 77-83.

Becker, Howard. Boys in White. Chicago: University of Chicago Press, 1961.

Blatterbauer, S., M.J. Kupst, and J. Schulman, M.D. "Enhancing the Relationship between Physicians and Patient." Health and Social Work, 1 (1976), 45-57.

Braceland, F.J. "Pastoral Psychology, the Next Twenty Years in Relation to Medicine." Pastoral Psychology, 21 (1970), 16-22.

Bracht, Neil. "Health Care, the Largest Human Service System." Social Work, 19 (1974), 532-542.

Brody, S.J. "Common Ground, Social Work and Health Care." Health and Social Work, 1 (1976), 16-31.

Butryn, Zofia. Social Work in Medical Care. New York: Humanities Press, 1967.

Edelson, Eric. "The Changing Role of the Social Worker in Medical Education." Social Work, 10 (1965), 81-86.

Encyclopedia of Social Work. New York: Bond Printing Company. 1971 ed.

Forman, L.H., M.D. "The Physician and the Social Worker." American Family Physician, 13 (1976), 90-93.

Fuchs, Victor, M.D. Who Shall Live? New York: Basic Books, 1975.

Gang, S.G. "The Family Doctor and the Social Worker." Practitioner, 214 (1975), 673-675. 
Garfield, Sidney. "The Delivery of Medical Care." Scientific American, $222(1970), 15-23$.

Goldberg, Ruth. "The Social Worker and the Family Physician." Social Casework, 54 (1973), 489-95.

Grinnell, Richard, Nancy Kute, Ski Hunter, and Thomas Larson. "The Status of Graduate Level Social Work Teaching in Medical Schools." Social Work in Health Care, 1 (1976), 317-323.

Halberstam, M.J., M.D. "The Solo Physician's Response." Public Welfare, 28 (1970), 400-403.

Hanlon, N. "The Identity of a Profession." Social Worker, 42 (1974) $172-173$.

Harwin, B.G., Brian Cooper, M.R. Eastwood, and D.P. Goldberg. "Prospects for Social Work in General Practice." Lancet, 2 (1970), 559-561.

Hallowitz, E. "Innovations in Hospital Social Work." Social Work, 17 (1972), 89-97.

Hookey, Peter. "The Viability of Social Work in Group Medical Practice." Portland, 1975. (Mimeographed)

Klemer, Richard. "The Marriage Counselor in the Physician's Office." Journal of Marriage and the Family, 23 (1966), 287-292.

Korpella, J.W. "Social Work Assistance in Private Pediatric Practice." Social Casework, 54 (1973), 537-544.

Langford, John. "A Survey of Attitudes of General Practitioners to Social Workers." Medical Journal of Australia, 1 (1974), 433-434.

Levenstein, Sidney. Private Practice in Social Casework. New York: Columbia University Press, 1964.

Lincoln, J.A., M.D. and R. Twersky. "Social Worker in the Family Medical Center." Journal of Family Practice. 1 (1974), 34-37.

Low, Merritt, M.D. "Pediatricians should be a Model of Primary Care." Pediatric News, December 1976.

Lyng, F.M. "Social Services." Hospitals, 49 (1975), 111-113.

Morris, Robert. "The Place of the Social Worker in the Human Services." Social Work, 19 (1974), 519-531. 
Phillips, B., J.W. McCulloch, M.J. Brown, and N. Hambrow. "Social Worker and Medical Practice." Hospitals, 45 (1971), 76-79.

Ratoff, L., M.D. "More Social Workers for General Practice?" Journal of the College of General Practitioners, 23 (1973), 736-742.

Schonfeld, H.K., J.F. Heston, and I.S. Falk. "Numbers of Physicians Required for Primary Care." New England Journal of Medicine, 286 (1972), 571-576.

Schuster, Eugene, M.D. "Pediatrics, Social Work and Psychiatry, Overlapping Disciplines." Pediatrics, 7 (1951), 449-452.

Smith, David, M.D. Family Practice Clinic, University of Oregon Medical School, Portland, Oregon. Interview, 19 April 1977.

Strozier, A. and W. Ballinger, M.D. "The Social Worker and the Surgeon." Surgery, 78 (1975), 128-129.

Townsend, Edward, M.D. "The Social Worker in Pediatric Practice." American Journal of Diseases of Children, 107 (1964), 77-83.

Wishingrad, L., J.T. Shulruff, and Alice Sklansky. "The Role of the Social Worker in a Private Practice of Pediatrics." Pediatrics, 32 (1963), 125-128. 
$X I 0 N 1 \exists d d \forall$ 
TABLE

APPROPRIATENESS OF PRACTICE SETTING BASED ON YEARS IN PRACTICE

\begin{tabular}{|c|c|c|c|c|}
\hline & \multicolumn{2}{|c|}{$\begin{array}{c}10 \text { Years or Less } \\
n=17\end{array}$} & \multicolumn{2}{|c|}{$\begin{array}{c}11 \text { Years or More } \\
n=39\end{array}$} \\
\hline & $\mathrm{n}$ & 10 & $n$ & $\%$ \\
\hline \multicolumn{5}{|l|}{$\begin{array}{l}\text { Affiliated in offices } \\
\text { with Physicians } \\
\end{array}$} \\
\hline Very Appropriate & 1 & 5.8 & 4 & 10.0 \\
\hline Somewhat Appropriate & 9 & 52.9 & 13 & 33.0 \\
\hline $\begin{array}{l}\text { Not Appropriate and } \\
\text { No Opinion }\end{array}$ & 7 & 41.0 & 22 & 56.0 \\
\hline \multicolumn{5}{|l|}{$\begin{array}{l}\text { In Private Social Work } \\
\text { Practice }\end{array}$} \\
\hline Very Appropriate & 5 & 29.4 & 10 & 25.0 \\
\hline Somevihat Appropriate & 8 & 47.0 & 16 & 41.0 \\
\hline $\begin{array}{l}\text { Not Appropriate and } \\
\text { No Opinion }\end{array}$ & 16 & 23.0 & 13 & 33.0 \\
\hline
\end{tabular}


39

You are one of a few randomly selected primary care physicians in private practice in Portland, who I am asking to please answer this brief questionnaire on the subject of medical social workers.

I would like the information (you remain anonymous) so that I can complete my research practicum, graduate with a degree of Vaster in Social work from Portland State University, and become self-sufficient.

Please complete the questionnaire and return it in the enclosed self-addressed stamped envelope.

Thank you very much for your cooperation.

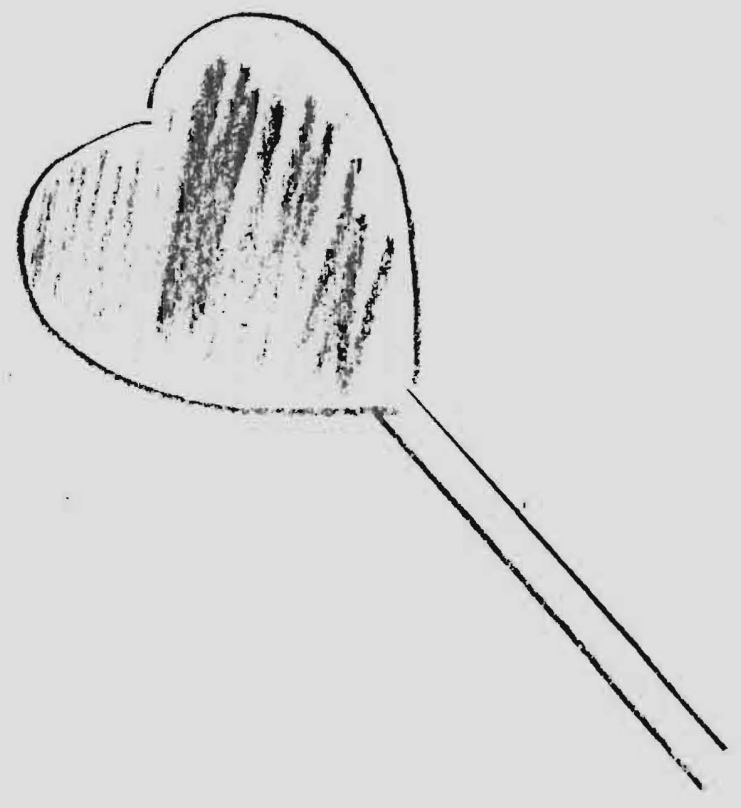

sincerely, Somacivoryald 
1. How familiar are you with the role and function of medical social workers? very faniliar somewhat familiar unfaniliar no opinion

2. Do you ever refer pationts to a social worker for counseling or other help? yes__ no___. If yes, for help with what kinds of problems?

3. Based on your experience, please rate the following as to their ability to do psycho-social counseling:

psycholoyist
clergyman
medical social worker
psychiatrist

4: riow appropriate are each of the following practice settings for medical social workers?

$$
\begin{array}{lll}
\text { very } & \text { somewhat } & \text { not } \\
\text { appropriate } & \text { appropriate } & \text { appropriate }
\end{array}
$$

community hospital
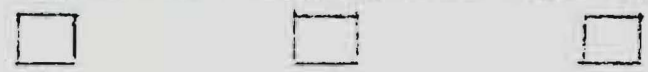

no opinion

private social

work practice
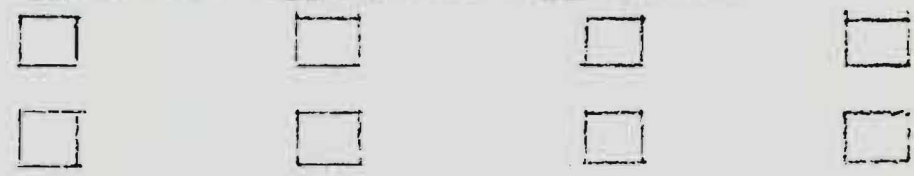

affiliated in offices vith physicians

social service agency
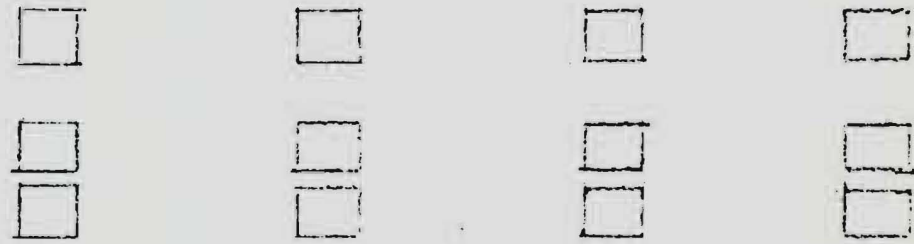

5. How many times a month do you refer patients to a social service agency? To which agencies do you refer most frequently?

6. Could you use a person with the skills of a medical social worker in your office? yes no iny?

7. That is of your pationts vould you estimato have emotional pro lons?

3. Ho: many years have you been in private practice?

9. Have you any other coraments about medical social workers?

Thank you verJ much.

please return to:

Rosemarie liosenfeld $4500 \mathrm{s.a.}$. Dormsview Court Portland, Or. 972215 